UDC 539.3

\title{
THE PARAMETRIC OSCILLATIONS OF ROTATING RODS UNDER ACTION OF THE AXIAL BEAT LOAD
}

\author{
V.O. Nedin \\ Kyiv National University of Construction and Architecture, \\ 31, Povitroflotskiy avenue, Kyiv, Ukraine
}

DOI: $10.32347 / 2410-2547.2020 .104 .309-320$

\begin{abstract}
The paper presents the results of investigation of the axial beat loads' influence on the transverse rotating rods' oscillations and their stability. The perforator's long drills are considered as objects of investigation.

The analysis of different author's papers that are studded the dynamics of oscillations of shafts and rotating rods is carried out. The relevance of the research topic is substantiated. The model of the considered dynamic system is described and equations of oscillations in space are given.

The technique for investigation is presented. This technique is based on search for new bend forms of rotating rod by solving the equations of oscillations with using the Hubbolt time integration method and the polynomial functions (splines) that are described the current bend form. In it, the spline functions are found by current bend form approximation where each of the found functions is responsible to certain point of rod elastic line and describes the position of nearby points.

Described technique was realized in a computer program with graphic user interface that is developed by author. Program allows to monitor for dynamics of the oscillatory motion of the modeled system in real-time by calculating and drawing the current band forms of the rotating rod during the oscillation.

Diagrams with regions of stable and instable motion of the rods, that were found by different parameters and boundary conditions are shown. The analysis of the results is obtained and the conclusion about possibility of operating the equipment in certain frequency ranges is done. The space oscillating process of rotating rods is considered with account of the gyroscopic loads and geometric nonlinearity.
\end{abstract}

Keywords: numerical differentiation, complex bend forms, spline, geometric nonlinearity, axial loads, hammer drills.

Introduction. The tasks of stress-deformed state and oscillations of elastic rotating rods, shafts and rotors have actuality while structural elements of machines and devices are designed. The rotating rods, shafts and rotors are responsible elements in the constructions of engines, turbines, wind and hydropower plants, drill strings and other machines. For these objects the cause of the development of oscillations can be both inertial loads and periodic external loads, such as periodic axial loads.

For example, during the operation of drill string the influence of bottom hole reaction can be periodical as a result of its transverse oscillations, at which the axial moving of its movable end occurs. During the operation of industrial hammer drill the action on the drill is periodic too. During the movement of vessels, the periodic influence on the shaft from propeller can happen, when the vessel passes through turbulent zones. Also in shafts, the periodic influence can 
be brought from oscillation of the adjacent section, which is transmitted through the coupling due to axial movements.

In recent years, the dynamic tasks of oscillations of shafts and rotating rods were investigated in works of many authors.

The dynamic behavior of drill strings in super-deep wells was considered in papers $[4,5]$. The column is modeled by vertical rod, taking into account the longitudinal loads and torque at its lower end. The critical rotational speeds were calculated with various values of external loads that are taken into consideration. The modes of natural oscillations and buckling of the drill string were found. The task is viewed in space taking into account the centrifugal and coriolis inertial loads, also by axial loads with constant values.

The task of rotating shaft with influence of axial loads to the propagation characteristics of the elastic waves is studied in paper [14]. The shaft is viewed with non-uniform cross-sections per length. Axial loads considered with constant values.

The oscillations of shafts and rods under the action of periodic loads were considered in different papers. The paper [10] presents the study of problems with elastic stabilization and long-term strength of the system under cyclically changing external impacts that are appearing because of eccentricities. Task is considered taking into account gyroscopic loads, in linear statement. The paper [9] presents the results of study of space bending oscillations of horizontal rod that is rotating around its axis. Rod is under the action of periodic harmonic force of self-weight per length. The task is considered taking into account gyroscopic loads, too.

Questions about the transverse oscillations of the rods under the action of axial periodic loads, also the tasks of longitudinal-transverse oscillations under the action of beat loads are considered in papers [7, 8]. But in them the investigated rods don't rotate.

In nonlinear statement the dynamics of the drill operation is considered in paper [13], taking into account the axial periodic impact force, but with the aim of studying the vibrations that occur in the coupling.

As result of review we can see, that investigating the dynamics of considered objects, the parametric oscillations of rotating rods under the action of periodic axial beat loads have an opened interest. This is due to actuality of the tasks of vibratory drilling of deep holes.

This paper presents the results of investigating the dynamic behavior of perforators' long drills under action of an axial beat load. It study has interest for long flexible drills.

Problem statement. In the process of oscillation of such rotating rods with various lengths, under the action of external periodic forces, the various bending forms that change in time are possible. Beside this, the various character of the oscillatory motion itself for various physical, geometric and dynamic parameters are possible too.

As a dynamic model is considered a rod with length $l$ (Fig. 1) that is under the action of periodic axial load $P(t)$. The rod rotates with an angular rotational 
speed $\omega$ around the rectilinear axis $O_{1} X_{1}$ of the stationary coordinate system $O_{1} X_{1} Y_{1} Z_{1}$. The rotating coordinate system $O X Y Z$ is tied to the rod and rotates with it. The direction of $O X$ axis coincides with direction of $O_{1} X_{1}$ axis. Axis of rod in deformed state is coinciding with the $O X$ and $O_{1} X_{1}$ axis. The oscillatory motion of the rod in the $O X Y Z$ coordinate system is characterized by $y(x, t)$ and $z(x, t)$ displacements of the points, that belong to the axis of rod, in the $O Y$ and $O Z$ coordinate axes' direction, respectively.

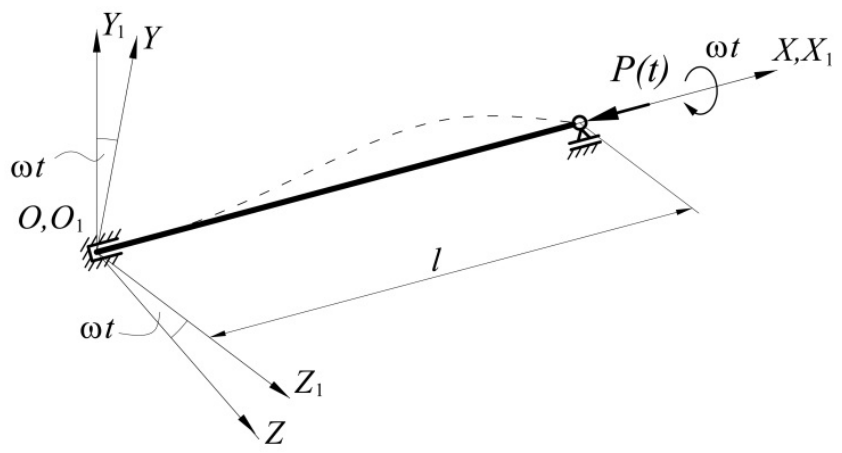

Fig. 1. Dynamic model of system.

In this statement, the oscillations of such rotating objects in space are described by the corresponding system of differential equations [11], which taking into account the geometric nonlinearity and the axial periodic force [3] have a form:

$$
\left\{\begin{array}{l}
\frac{d^{2}}{d x^{2}}\left(\frac{E I_{1(x)}}{\rho_{1}}\right)-\bar{m} r^{2}\left(\frac{d^{4} y}{d t^{2} d x^{2}}+\omega^{2} \frac{d^{2} y}{d x^{2}}\right)-2 \omega \bar{m} \frac{d z}{d t}-\bar{m} \omega^{2} y+\bar{m} \frac{d^{2} y}{d t^{2}}+ \\
+P(t) \frac{d^{2} y}{d x^{2}}=0 \\
\frac{d^{2}}{d x^{2}}\left(\frac{E I_{2(x)}}{\rho_{2}}\right)-\bar{m} r^{2}\left(\frac{d^{4} z}{d t^{2} d x^{2}}+\omega^{2} \frac{d^{2} z}{d x^{2}}\right)+2 \omega \bar{m} \frac{d y}{d t}-\bar{m} \omega^{2} z+\bar{m} \frac{d^{2} z}{d t^{2}}+ \\
+P(t) \frac{d^{2} z}{d x^{2}}=0,
\end{array}\right.
$$

where $E$ - elastic modulus of rod's material; $I_{1}, I_{2}$ - inertia moments of rod section in mutually perpendicular planes; $r$ - radius of gyration; $\bar{m}$-mass of unit per length; $\omega$-rotational speed of rod around the axis that is coincided with the axis of rod in undeformed state; $P(t)$ - periodic axial force; $1 / \rho_{1}, 1 / \rho_{2}-$ main curvatures of rod's axis in mutually perpendicular planes in form: 


$$
\frac{1}{\rho_{1}}=\frac{\frac{d^{2} y}{d x^{2}}}{\left(1+\left(\frac{d y}{d x}\right)^{2}\right)^{3 / 2}}, \frac{1}{\rho_{2}}=\frac{\frac{d^{2} z}{d x^{2}}}{\left(1+\left(\frac{d z}{d x}\right)^{2}\right)^{3 / 2}} .
$$

If the rod is under the influence of an axial beat load, this action is modeled by function, that looks like as: $P(t)=P_{\max } \cdot\left(a^{1+\cos \theta t}-a^{2}\right)$, for which the changes of amplitude in time is shown in Figure 2.

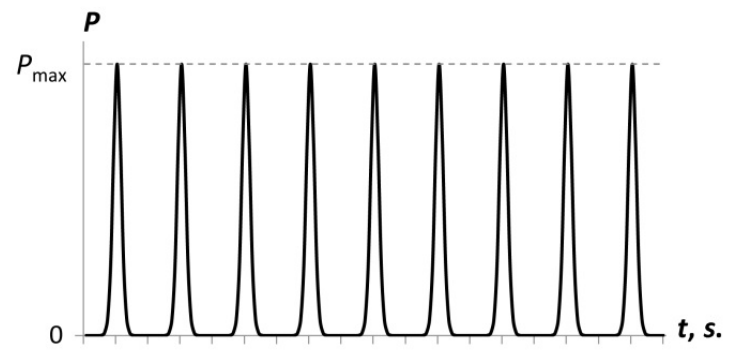

Fig. 2. The diagram of function $P(t)$

Technique. For investigation of the dynamics of motion for considered objects in this paper propose to use the technique in which the process of oscillation is modeled based on repeated (cyclic) solving the system of differential equations for every point of system in order to find the new coordinates of positions for these points in each next point of time $t+\Delta t$.

In it, the solving of equations (1) for searching of new bend form for the next point of time is based on the use of polynomial functions (splines) [1] that describe the current bend form and the Houbolt time integration method [12]. The spline functions [6], in turn, are determined by approximating the current bend form, where each of found functions is responsible to certain point of rod elastic line and describes the position of nearby points.

In result of the approximation, the line of the current bend is described by the array of $n$ polynomial functions $f_{n}(x)=a_{n 0}+a_{n 1} x+a_{n 2} x^{2}+a_{n 3} x^{3}+a_{n 4} x^{4}$, each of which corresponds to certain point of rod elastic line and tied with nearby points (Fig. 3).

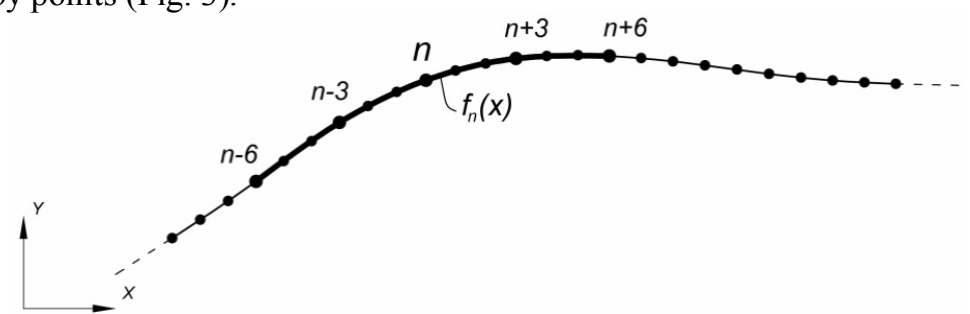

Fig. 3. Bend form approximation for point $\mathrm{n}$ to function $f_{n}(x)$ 
The search process of each functions $f_{n}(x)$, namely coefficients $a_{n 0}, a_{n 1}, a_{n 2}$, $a_{n 3}, a_{n 4}$, can be executed by the coordinates of points $n-2, n-1, n+1, n+2$, that lie near point $n$. However, it is necessary that the functions of all derivatives of spline have been continuous and smooth lines. Therefore, these points are considered as intermediate and used to control of continuity and smoothness. The approximation executes by coordinates of points $n-6, n-3, n+3, n+6$ and current $n$, which are considered like as characteristic.

The calculation of the coefficients $a_{n 0}, a_{n 1}, a_{n 2}, a_{n 3}, a_{n 4}$, for each function, executes by solving the system of five equations (2) using the coordinate values of each of five points that belong to considered part of rod elastic line

$$
\left\{\begin{array}{l}
a_{n 0}+a_{n 1} x_{n-6}^{1}+a_{n 2} x_{n-6}^{2}+a_{n 3} x_{n-6}^{3}+a_{n 4} x_{n-6}^{4}=y_{n-6} \\
a_{n 0}+a_{n 1} x_{n-3}^{1}+a_{n 2} x_{n-3}^{2}+a_{n 3} x_{n-3}^{3}+a_{n 4} x_{n-3}^{4}=y_{n-3} \\
a_{n 0}+a_{n 1} x_{n}^{1}+a_{n 2} x_{n}^{2}+a_{n 3} x_{n}^{3}+a_{n 4} x_{n}^{4}=y_{n} \\
a_{n 0}+a_{n 1} x_{n+3}^{1}+a_{n 2} x_{n+3}^{2}+a_{n 3} x_{n+3}^{3}+a_{n 4} x_{n+3}^{4}=y_{n+3} \\
a_{n 0}+a_{n 1} x_{n+6}^{1}+a_{n 2} x_{n+6}^{2}+a_{n 3} x_{n+6}^{3}+a_{n 4} x_{n+6}^{4}=y_{n+6}
\end{array} .\right.
$$

Found functions $f_{n}(x)$ are differentiated and found derivatives are used to solve the system of differential equations for each point of rod elastic line separately for searching of next bend form for next point of time $t+\Delta t$.

Boundary conditions. Using the considered technique the boundary conditions at the ends of the rod are modeled by schemes based on imaginary prolongation of the elastic line of the rod. Let's consider few basic boundary conditions.

The hinged boundary at the end of the rod is modeled by analogic scheme, but for the end point. namely, for searching the function for point $m$, use the value $y_{m}=0$, and assumed that for $x_{m+1}=\left(2 x_{m}-x_{m-1}\right), x_{m+2}=\left(2 x_{m}-x_{m-2}\right)$, the values $y_{m+1}=-y_{m-1}, y_{m+2}=-y_{m-2}$, respectively. the points $m+1, m+2$ belong to the line of the imaginary continuation of the rod elastic line and their coordinates are determined by corresponding relations using the coordinate's values in points $m-1$ and $m-2$. such relations give that every time after approximation we get a function whose value in point $m$ will be $y_{m}=0$, and the value of its second derivative will be $y_{m}{ }^{\prime \prime}=0$.

The pinched boundary at the beginning of the rod is modeled by scheme, where, for point 0 , use the values $x_{0}=0, y_{0}=0$, and assumed that for $x_{-1}=-x_{1}, x_{-2}=-x_{2}$, the values $y_{-1}=y_{1}, y_{-2}=y_{2}$, respectively. such relation gives that every time after approximation we get a function whose value in point 0 will be $y_{0}=0$, and the value of its second derivative will be $y_{0}{ }^{\prime \prime} \neq 0$.

The pinched boundaries at the end of the rod are modeled by scheme, where, for point $m$, use the value $y_{m}=0$, and assumed that for $x_{m+1}=\left(2 x_{m}-x_{m-1}\right), x_{m+2}=$ $\left(2 x_{m}-x_{m-2}\right)$, the values $y_{m+1}=y_{m-1}, y_{m+2}=y_{m-2}$, respectively. such relations give 
that every time after approximation we get a function whose value in point $m$ will be $y_{m}=0$, and the value of its second derivative will be $y_{m}{ }^{\prime \prime} \neq 0$.

For beginning of the oscillatory motion, it is necessary that the system be out of equilibrium, in which the rod will take the initial bend form. Such action can be caused by the action of random instant load.

During the operation of hammer drills, one of such instant loads can be the bending moment that occurs at the end of the drill due to the uneven strength of particles of concrete that are crashed by beating.

In this representation, the action of the bending moment is modeled by onetime instant load at the end of the rod and the required initial bend form is determined by the method of initial parameters.

The initial bend form is found for the time $t=0$, like a point of start of oscillation, believing, that the action of inertial loads is absent, since before the start of oscillations the axis of the rod in undeformed state passes through the axis of rotation.

So, in this way, the analysis of the geometric position of rotating rod in space, the approximation of bend form (elastic line) and its differentiation is a first component of solving the equations of oscillations and performs in conditionally fixed moment in time.

The oscillatory motion, especially during rotation, is a dynamic process in which at each next moment in time not only the geometric positions of all points of the system have changes, but such parameters as rotation angles, speeds and accelerations have changes too. Therefore, the second component of solving the equations is the solve of task in time, that performs using the numerical Houbolt integration method, in which makes the search of new bend form for each next point of time $t+\Delta t$, based on current bend form and its derivatives.

Realization note. The considered technique is the basis component of the algorithm for the numerical solving of the differential equations of oscillations by rotation of rod systems in space and time. The algorithm realized by computer program with graphic user interface that helps to monitor for the dynamics of oscillating process of modeled system in real time. Besides this, the program gives the capacity to make the analysis of behavior of modeled system, find the dynamic instability fields and draw the diagrams of found fields. Moreover, the program draws the graphics of oscillations and changes of angular speeds and accelerations.

Results. In this paper shown the results of investigating the dynamic behavior of perforators' long drills under action of an axial beat load that were gotten by described technique and program. Among them: long drills with length $800 \ldots 1000 \mathrm{~mm}$ and diameter $10 \ldots 22 \mathrm{~mm}$, boers with length $900 \ldots 1000$ $\mathrm{mm}$ and diameter of rod $18 \ldots 22 \mathrm{~mm}$, extensions for drills with length $750 \ldots 1100 \mathrm{~mm}$ and diameter of rod $18 \mathrm{~mm}$.

The priority amounts of industrial hammer drills with an SDS Max type chuck operate on rotational speeds in range of $\omega=25 \ldots 75 \mathrm{~s}^{-1}$ and beat frequencies in range of $\theta=170 \ldots 380 \mathrm{~s}^{-1}$. Household hammer drills with an SDS 
Plus type chuck operate on rotational speeds in range of $\omega=75 \ldots 250 \mathrm{~s}^{-1}$ and beat frequencies in range of $\theta=380 \ldots 580 \mathrm{~s}^{-1}$.

During rotation with different speeds under action of an external periodic force with different frequencies the oscillations' amplitude can be constant (with critical parameters), fading out or growing up. This characterizes the stable or instable behavior of an object in such dynamic process.

For example, for steel rod with diameter $d=12 \mathrm{~mm}$ and length $l=1 \mathrm{~m}$ during rotation with critical speed of the 1 -st harmonic that is equal $145.5 \mathrm{~s}^{-1}$, but without action of external forces, the transverse oscillations in the rotating coordinate system do not occur (because rod is in equilibrium of inertial and elastic forces). In stationary coordinate system, the oscillations occur with constant amplitude as the projection on the coordinate planes. Herewith, under the action of periodic axial beat load with frequency that is equal to the value of critical rotational speed, the oscillations occur with growing amplitude, which in the projection on the coordinate axes have the form shown in Fig. 4.
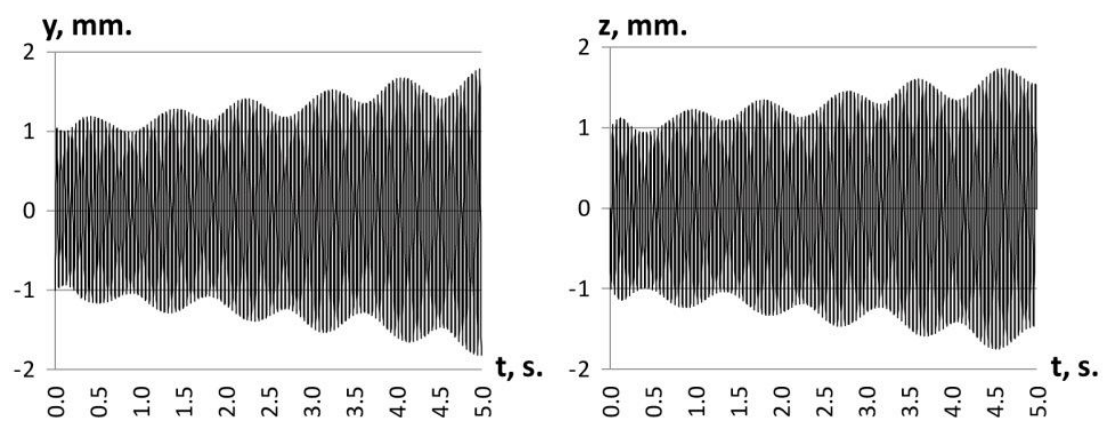

Fig. 4. Oscillations of steel rod that is rotated with speed equal $145.5 \mathrm{~s}^{-1}$, under action of the axial beat load with frequency equal $145.5 \mathrm{~s}^{-1}$.

Therefore, such oscillatory motion of rotating rod is instable and since over the time it will have been destroyed because of constant amplitude growth.

As results of study of mentioned objects in Figures 5-9 the fields of stable and instable oscillations by rotation are presented. These fields show instable regions in depends of rotational speeds $\omega$ and beat frequencies $\theta$, which were found for the reviewed objects by various geometric, physical parameters and boundaries. Figures 5-7 show the results for rods with hinged boundaries at both ends. Figures 8 and 9 show the results in case when one end of rod is pinched other is hinged.

The fields of instable oscillations are displayed filled gray. White colored regions are the fields of stable oscillations. The rectangles with dashed borders show the operating frequency ranges for priority amounts of industrial hammer drills with SDS Max type chuck and household hammer drills with SDS Plus type chuck. Numerically these ranges are presented upper in this part. 


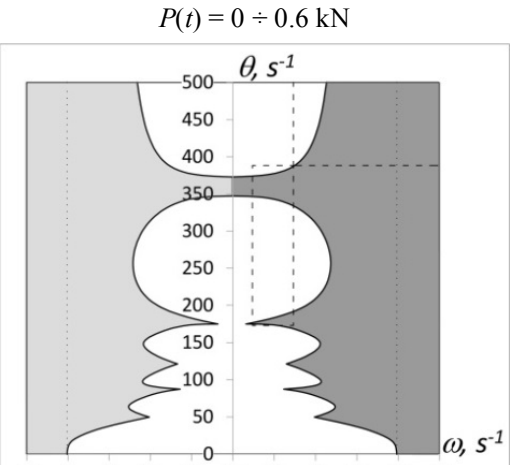

品宗品 욱

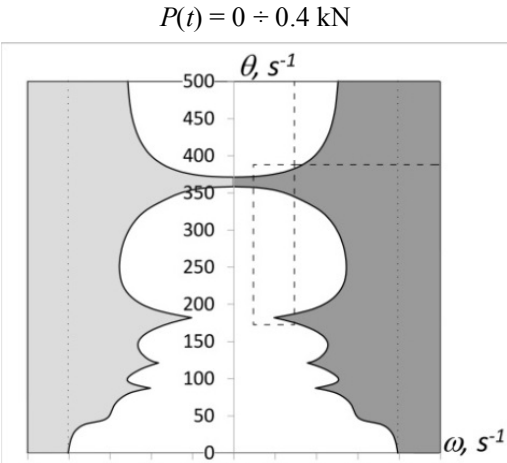

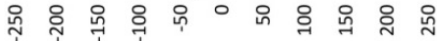

Fig. 5. Dynamic instability fields of rods with diameter $d=10 \mathrm{~mm}$, length $l=0.8 \mathrm{~m}$, under action of axial beat load $P(t)$, with hinged boundaries

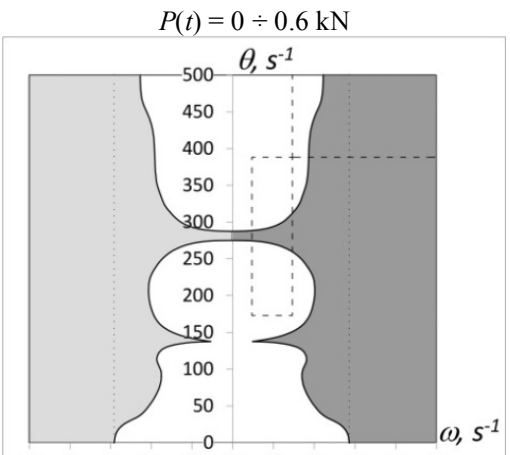

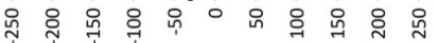

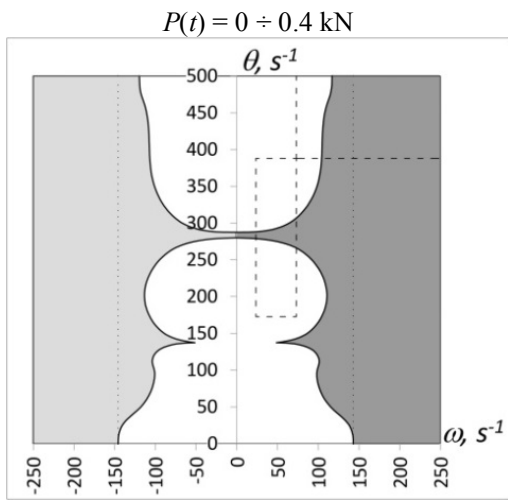

Fig. 6. Dynamic instability fields of rods with diameter $d=12 \mathrm{~mm}$, length $l=1 \mathrm{~m}$, under action of axial beat load $P(t)$, with hinged boundaries
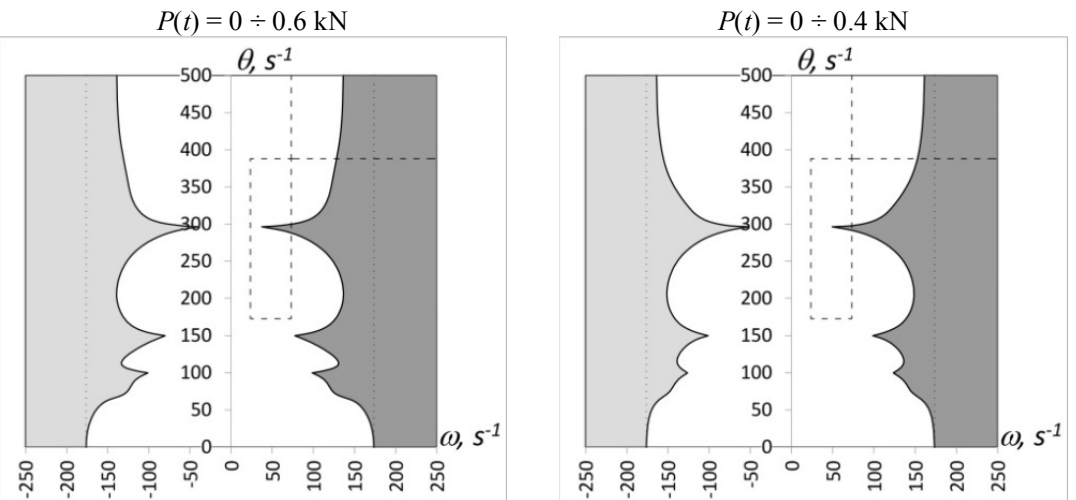

Fig. 7. Dynamic instability fields of rods with diameter $d=18 \mathrm{~mm}$, length $l=1.2 \mathrm{~m}$, under action of axial beat load $P(t)$, with hinged boundaries 


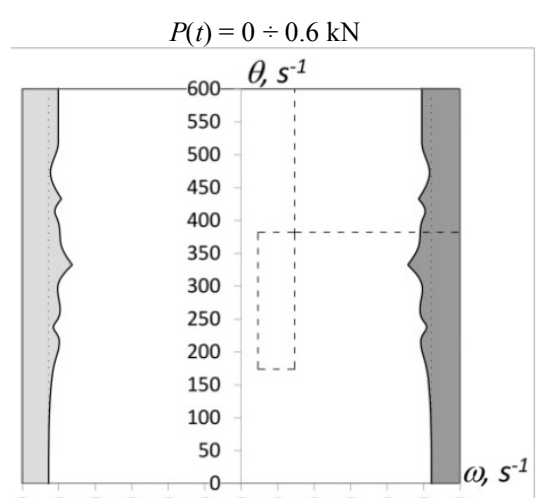

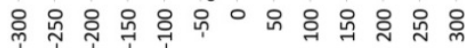

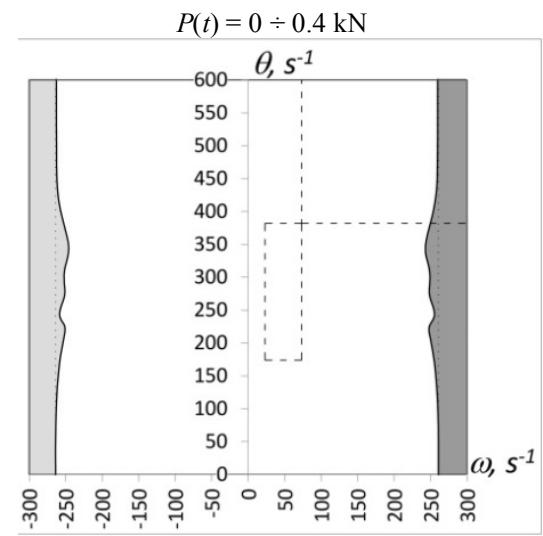

Fig. 8. Dynamic instability fields of rods with diameter $d=10 \mathrm{~mm}$, length $l=0.8 \mathrm{~m}$, under action of axial beat load $P(t)$, with pinched and hinged boundaries
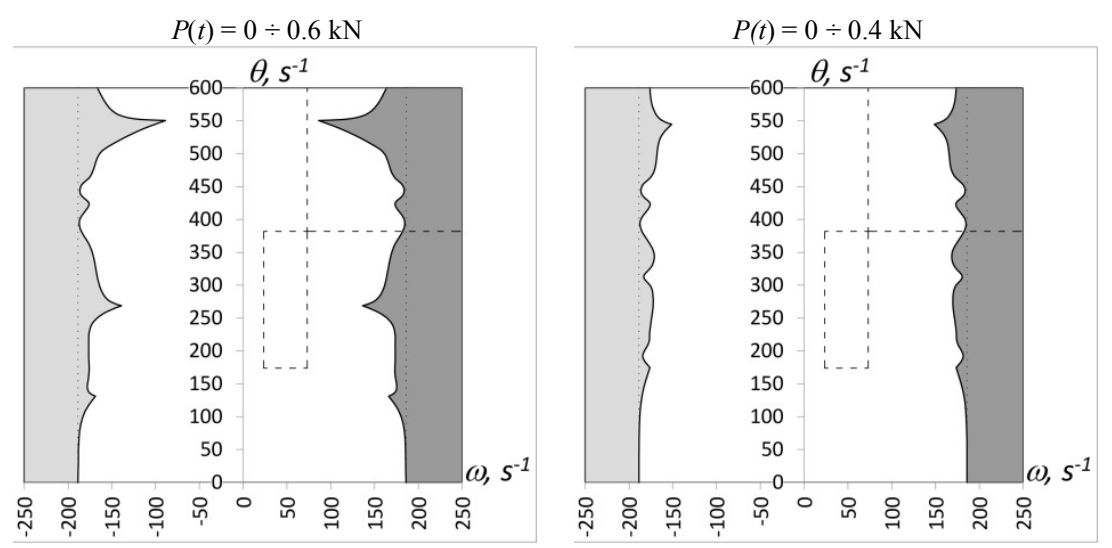

Fig. 9. Dynamic instability fields of rods with diameter $d=12 \mathrm{~mm}$, length $l=1 \mathrm{~m}$, under action of axial beat load $P(t)$, with pinched and hinged boundaries

As we can see from diagrams, for various steel rods with their parameters and different boundary conditions there are frequency ranges at which the drills of perforator in use will start instable oscillations and over the time they can be destroyed.

So, for example, for industrial hummer drills, such regions are observed for rods with diameter $d=10 \mathrm{~mm}$ and length $l=0.8 \mathrm{~m}$ (Fig. 5), with diameter $d=12 \mathrm{~mm}$ and length $l=1 \mathrm{~m}$ (Fig. 6), with diameter $d=18 \mathrm{~mm}$ and length $l=1.2 \mathrm{~m}$ (Fig. 7), with hinged boundary conditions. And in fact there are in rather narrow ranges.

For household hammer drills that are using in higher frequency ranges, as we can see from the diagrams, the instable regions are much wider and observed both: under hinged boundary conditions at the ends and with boundary conditions where one end is pinched other is conditionally hinged. 
Conclusion. The considered results of investigation of the axial beat loads' influence on the stability of rotating rods in space, studding perforator's long drills as example, show, that for certain ratios of rotation and beat frequencies there are regions of instable oscillatory motion in which running the equipment can inevitably lead to its destruction, that can turn to undesirable injuries or tragic consequences either at work or at home.

\section{REFERENCES}

1. Ahlberg J., Nilson E., Walsh J. Teoriya splaynov i ee primenenie (Spline theory and its application). M.: Mur, 1972, 319 pp.

2. Bakhvalov N.S., Judkov N.P., Kobelkov G.M. Chislennye metody (Numerical methods). M.: BINOM, Laboratoriya znaniy, 2015, 639 pp.

3. Bolotin V.V. Dinamicheskaya ustoychivost uprugih system (The dynamic stability of elastic systems). M.: Izdatelstvo tekhniko-teoreticheskoj literatury, 1956, $600 \mathrm{pp}$.

4. Gulyayev V. I. Bifurkatsionnoye vypuchivaniye vertikalnykh kolonn sverkhgdubokogo bureniya (Bifurcational buckling of vertical super-deep drilling columns) / V.I. Gulyayev, V.V. Gaydaychuk, I.V. Gorbunovich // Promyslove budivnytstvo ta inzhenerni sporudy. -2009. - No. 2. - S. $10-15$.

5. Gulyayev V. I. Kompyuternoye modelirovaniye dinamiki konstruktsiy ustanovok glubokogo bureniya (Computer modeling of dynamics of deep drilling rigs' constructions) / V. I. Gulyayev, V.V. Gaydaychuk, S.N. Xudolij // Zbirnyk naukovykh prats $\square$ Ukrayins $\square$ koho naukovo-doslidnoho ta proektnoho instytutu stalevykh konstruktsiy imeni V. M. Shymanovskoho. - 2009. - Vip. 4. - S. 208-216.

6. Zavyalov YU.S., Kvasov B.I., Miroshnichenko V.L. Metody splajn-funkcij (Spline functions methods). M.: «Nauka», 1980, 352 pp.

7. Morozov N.F. Static and Dynamics of a Rod at the Longitudinal Loading / N.F. Morozov, P.E. Tovstik, T.P. Tovstik // Vestnik YUUrGU. Seriya «Matematicheskoye modelirovaniye i programmirovaniye». - 2014. - Vol. 7, No. 1. - S. 76-89.

8. Morozov N.F. The rod dynamics under short longitudinal impact / N.F. Morozov, P.E. Tovstik // Vestnik SPbGU. - 2013. - Vup. 3. P.131-141.

9. Munitsyn A.I. Prostranstvennyye izgibnyye kolebaniya sterzhnya, vrashchayushchegosya vokrug svoyey osi (Space bending oscillations of a rod rotating around its axis) // Matematicheskoye i kompyuternoye modelirovaniye mashin i sistem. - 2008. S. 64-67.

10. Murtazin I.R. Research of flexural vibrations of rotating shafts with distributed inertial, elastic and eccentricity properties / I.R. Murtazin, A.V. Lukin, I.A. Popov // Scientific and Technical Journal of Information Technologies, Mechanics and Optics. - 2019. - Vol. 19, no. 4, P. 756766.

11. Tondl A. Dinamika rotorov turbogeneratorov (The rotor dynamics of turbines). L., Energiya, 1971, $297 \mathrm{pp}$.

12. Maurice Petyt. Introduction to Finite Element Vibration Analysis. Cambridge University Press, 1990. $-558 \mathrm{p}$.

13. Songyong Liu. Coupling vibration analysis of auger drilling system / Songyong Liu, Xinxia Cui, Xiaohui Liu // Journal of vibroengineering. - 2013. Vol. 15. - P.1442-1453.

14. Yimin Wei. Influence of Axial Loads to Propagation Characteristics of the Elastic Wave in a Non- Uniform Shaft / Yimin Wei, Zhiwei Zhao, Wenhua Chen and Qi Liu // Chinese Journal of Mechanical Engineering. - 2019 - No. 32:70. P.13. 
Недін B.O.

\section{ПАРАМЕТРИЧНІ КОЛИВАННЯ СТЕРЖНІВ, ЩО ОБЕРТАЮТЬСЯ ПІД ДІЕЮ ПОЗДОВЖНЬОГО УДАРНОГО НАВАНТАЖЕННЯ}

В роботі наведені результати дослідження впливу поздовжніх ударних навантажень на характер поперечних коливань стержнів, що обертаються та їх стійкість. В якості об'єктів дослідження обрані довгомірні робочі органи перфораторів, що мають значну гнучкість.

Здійснено аналіз публікацій різних авторів, які займаються дослідженням динаміки коливань валів та стержнів, що обертаються та обгрунтована актуальність обраної тематики дослідження. Описана модель динамічної системи, що розглядається, наведені рівняння коливального руху у просторі.

Представлена методика дослідження, яка будується на пошуку нових форм вигину стержнів при обертанні, через розв'язання рівнянь коливального руху з використанням поліноміальних функцій (сплайнів), що описують форму вигину, та методі інтегрування за часом Хубболта. В цій методиці сплайн-функції отримуються апроксимацією поточної форми вигину, де кожна 3 найдених функцій відповідає за певну точку пружної лінії стержня та описує положення сусідніх точок.

Наведені діаграми, що відображають області стійкого та нестійкого руху стержнів при різних параметрах та граничних умовах. Здійснено аналіз отриманих результатів та висновок про можливість експлуатації обладнання у певних діапазонах частот. Процес коливального руху розглянуто у просторі 3 урахуванням геометричної нелінійності стержня та гіроскопічних навантажень.

Ключові слова: чисельне диференціювання, складні форми вигину, сплайн, геометрична нелінійність, поздовжні навантаження, ударні навантаження, перфоратори.

\section{Недин В.О.}

\section{ПАРАМЕТРИЧЕСКИЕ КОЛЕБАНИЯ ВРАЩАЮЩИХСЯ СТЕРЖНЕЙ ПОД ДЕЙСТВИЕМ ПРОДОЛЬНОЙ УДАРНОЙ НАГРУЗКИ}

Рассматриваются некоторые результаты исследования влияния продольных ударных нагрузок на характер поперечных колебаний вращающихся стержней и их устойчивость. В качестве объектов исследования были выбраны длинномерные рабочие органы перфораторов со значительной гибкостью.

В работе осуществлён анализ публикаций разных авторов, занимающихся исследованием динамики колебаний валов и стержней, вращающиеся и обоснована актуальность тематики исследования. Описана модель рассматриваемой динамической системы, приведены уравнения колебательного движения в пространстве.

Представлена методика исследования, которая строится на поиске новых форм изгиба вращающихся стержней решением уравнений колебательного движения с использованием полиномиальных функций (сплайнов), описывающих текущую форму изгиба, и методе интегрирования по времени Хубболта. В этой методике сплайн-функции находятся аппроксимацией текущей формы изгиба, где каждая из найденных функций отвечает за определенную точку упругой линии стержня и описывает положение соседних точек.

Приведены диаграммы, отражающие области устойчивого и неустойчивого движения стержней при различных параметрах и граничных условиях. Осуществлен анализ полученных результатов и сделан вывод о возможности эксплуатации оборудования в определенных диапазонах частот. Процесс колебательного движения рассмотрен в пространстве с учетом гироскопических инерционных нагрузок на вращающийся стержень, а также с учётом геометрической нелинейности.

Ключевые слова: численное дифференцирование, сложные формы изгиба, сплайн, геометрическая нелинейность, продольные нагрузки, ударные нагрузки, перфораторы. 


\section{UDC 539.3}

Nedin V.O. The parametric oscillations of rotating rods under action of the axial beat load // Strength of Materials and Theory of Structures: Scientific-and-technical collected articles - Kyiv: KNUBA, 2020. - Issue 104. - P. 309-320.

The paper presents the results of investigation of the axial beat loads' influence on the transverse rotating rods' oscillations and their stability.

Tabl. 0. Fig. 8. Ref. 7.

\section{УДК 539.3}

Недін В.O. Параметричні коливання стержнів, що обертаються під дією поздовжнього ударного навантаження // Опір матеріалів і теорія споруд: наук.-тех. збірник. - К.: КНУБА, 2020. - Вип. 104. - С. 309-320.

В роботі наведені результати дослідження впливу поздовжніх ударних навантажень на характер поперечних коливань стержнів, щзо обертаються та їх стійкість.

Табл. 0. Іл. 8. Бібліогр. 7 назв.

Недин В.O. Параметрические колебания вращающихся стержней под действием продольной ударной нагрузки // Сопротивление материалов и теория сооружений. - 2020. Вып. 104. С. 309-320.

В работе представлены результаты исследования влияния продольных ударных нагрузок на характер поперечных колебаний вращающихся стержней и их устойчивость.

Табл. 0. Ил. 8. Библиогр. 7 назв.

Автор (вчена ступень, вчене звання, посада): асистент кафедри основ інформатики НЕДІН Валентин Олегович.

NEDIN Valentyn, assistant of professor of computer sciences chair.

Адреса робоча: 03680 Украӥна, м. Київ, Повітрофлотський проспект 31, Київський національний університет будівництва і архітектури, НЕДІН Валентин Олегович.

Роб. тел.: + 38(044) 241-54-62;

мобільний тел.: +38(067) 764-95-52;

E-mail: nvo@bigmir.net.

ORCID ID: http://orcid.org/0000-0003-3138-2892 